\title{
On-line interactions as a resource to raise pragmatic awareness
}

\begin{abstract}
Although the development of pragmatic competence is now a stated aim in foreign language curricula, few researchers believe that the language classroom can equip learners with the necessary tools to achieve this. The artificiality of most classroom activities and the language produced in them restrict quantity and quality of input to which learners are exposed, particularly through the models presented in most language textbooks. Researchers have shown that textbook explanations fall short in accurately describing speech act realisations and that the native-speaker intuitions of textbook writers do not match naturally occurring data. This study contributes to the discussion by exploring the speech act advice giving. It compares the pragmalinguistic features described in 12 intermediate Spanish language textbooks with natural data collected from on-line advice about relationship break-ups. The comparison shows great differences in the structures used and in the distribution of discourse strategies. Conclusions point to the importance of supplementing classroom materials with data from naturally occurring interactions, to expose students not only to pragmalinguistic features of the language but also to sociopragmatic norms of the target culture.
\end{abstract}

Keywords: advice; on-line data; textbook advice; pedagogy; Spanish

\section{Introduction}

The emergence of Communicative Language Teaching (CLT) as the dominant paradigm of foreign language instruction resulted in a reconceptualisation of language and of the abilities students need to develop to become competent speakers of the target language. The view underlying this paradigm is that language is not primarily a formal, standardised system, but "a social and cultural phenomenon" (Hymes, 1971; Kramsch, 1997) that is "acquired and used interactively, in a variety of contexts for myriad practical purposes" (Firth and Wagner, 1997: 296). Thus, developing communicative competence in a second language involves far more than learning the grammatical structures and rules of a target language; it involves acquiring the diverse linguistic tools and resources upon which cultural practices are rooted. In this view, language use rather than structure becomes a crucial object of inquiry, as language 'transports' cultural meaning (Dlaska, 2000: 250) and thus offers an opening into cultural mores.

The concept of communicative competence itself has evolved significantly over the last few decades since first formulated by Hymes (1971) and further developed in the 1980s, in an attempt to specify its diverse elements (see for instance M. Canale, 1983; Merrill Canale and Swain, 1980). It was not until the 1990s, however, that pragmatic competence, "the ability to use language effectively in order to achieve a specific purpose and to understand language in context" (Thomas, 1983: 92), was explicitly introduced into a model of communicative competence and recognised as one of its main components. Bachman (1990) proposed two main competences, 'organisational competence', which refers to formal aspects of the language and includes grammatical and discourse competence, and 'pragmatic competence', which includes both 'sociolinguistic competence', the knowledge of how to use language functions 
appropriate to the context, and 'illocutionary competence', the knowledge of speech acts. This division of pragmatic competence parallels the division of pragmatics by Leech (1983) and Thomas (1983) into pragmalinguistics, "the particular resources which a given language provides for conveying particular illocutions", and sociopragmatics, "the sociological interface of pragmatics", which involves understanding of contextual variables such as the social distance between participants in an interaction. Following these characterisations, it becomes clear that adopting the development of communicative competence as the aim of foreign language instruction implies adopting a pragmatic approach.

\section{Pragmatic competence and the foreign language classroom}

Despite the profound changes that the expanded conceptualisation of 'communicative competence' entails, there is little consensus among foreign language instructors and applied linguists on how to translate this view into classroom practice. First, there is almost general recognition by now that culture needs to be integrated into language teaching, but the results of these efforts have so far been meagre and, at university level, the dissociation between culture and language - mostly understood as grammatical competence in the Chomskyan sense (Chomsky, 1965) - still characterises most courses and curricula. When culture is incorporated, the focus is still on big achievements or key products of a civilisation ('Culture' with a capital C), or on vignettes of everyday living ('culture' with lower c). Classes usually give minimal time to exploring the underlying norms and values that impact on ways of thinking and doing. More important, both the practices for teaching culture and the materials used in class typically provide learners few opportunities to explore the richness of the target cultures and languages, instead promoting essentialist, static, and monolithic image.

Given that most foreign language instruction is provided in the classroom with little or no exposure to the target language community, it is fitting to ask whether (and how) the classroom can be used to provide learners with opportunities to engage in the types of social interactions needed to develop communicative competence through engagement and contextualisation (de Bot et al., 2005: 83). Many researchers believe this is not possible (Seedhouse, 1996), due to the artificiality of most classroom activities and the language produced in them, and the quantity and quality of input to which learners are exposed. Most language textbooks present models that lack authenticity or are pragmatically inappropriate.

Pragmatics, the subfield of linguistics concerned with the study of the use of language in context, by real speakers and hearers in real situations, shows great potential to promote this sort of understanding. If the aim of foreign language instruction is to develop learners' communicative competence, acquisition of pragmatic competence is a sine qua non; learners cannot participate in everyday interactions in a variety of contexts without it. There is ample evidence that "grammatical competence does not guarantee a corresponding level of pragmatic development" (Bardovi-Harlig and Dörnyei, 1998: 234). Learners therefore need to engage with materials or in learning situations that go beyond tokens of language isolated from the linguistic and nonlinguistic contexts in which they occur. They need to explore language as both linguistic and social actions within specific contexts (Liddicoat, 1997). This is particularly important since research has shown that while native speakers tend to be 
tolerant with non-native speakers' phonological, syntactic and lexical errors, which they take as reflecting learners' as-yet incomplete acquisition of the linguistic code, they negatively evaluate non-native speakers who lack pragmatic competence. Users of inappropriate language run the risk of being perceived as uncooperative, rude or insulting (Bardovi-Harlig, Hartford, Mahan-Taylor, Morgan and Reynolds, 1991; Thomas, 1983).

Language teaching textbooks fall short in this respect (Bardovi-Harlig and Dörnyei, 1998). Textbooks typically contain little information about language use (Boxer and Pickering, 1995; Vellenga, 2004). A few studies that investigated speech-act presentation in pedagogical materials, particularly in English, noted mismatch between textbook writers' intuitions of native speakers' speech and natural language use. These materials present language that reflects explicit knowledge of how native speakers should speak rather than tacit knowledge of how they actually speak. Boxer and Pickering's study (1995) of complaints' treatment in seven ELT textbooks found that the surveyed textbooks mostly ignored sociolinguistic variables that play a crucial role in users' selection of linguistic structures, and focused on very restricted environments to illustrate the speech act under consideration. Having reached a similar conclusion in their study of conversation closing in 20 ESL textbooks, Bardovi-Harlig et al. (1991: 4) argue that learners need to be exposed to authentic materials that reflect spontaneous language use and to "language samples which observe social, cultural, and discourse conventions - or in other words, which are pragmatically appropriate”. They conclude that teachers need to equip learners with not only structural aspects of the language but with the pragmatics as well. The common conclusion of this line of research is that pragmatic competence is teachable (Cohen, 2005; Kasper, 1997; Kasper and Rose, 2002; Martínez-Flor and Alcón Soler, 2007; Matsumura, 2001), and that instructional materials need to use findings from empirical studies to introduce learners to a variety of speech acts in diverse contexts, rather than depend on instructors' or textbook writers' intuitions.

This paper aims to extend the discussion into teaching of Spanish language, by exploring one particular speech act, advice giving, in one particular medium, on-line. After briefly discussing some aspects of advice giving and politeness both off and online, I survey advice presentation in 12 intermediate Spanish language textbooks focusing on the pragmalinguistic and sociopragmatic information (or its absence) in these books. I follow with discussion of a survey I conducted of advice on relationship break-ups provided on internet advice-needed sites as an example of one particular type of authentic interaction. My comparison of the two data sets reveals great discrepancies between them, which highlights the importance of supplementing classroom materials with data from naturally occurring interactions. These data can expose students not only to extensive pragmalinguistic resources of the target language but also to sociopragmatic norms of the target culture.

\section{Advice, indirectness and politeness}

Advice, solicited or unsolicited, is a directive speech act (Searle, 1969) in which one participant tries to change or guide another's behaviour. Researchers agree that advice giving potentially threatens the self-image of the advice receiver (Locher, 2006; Morrow, 2006), so advice givers may use discourse strategies to reduce this threat and make their advice acceptable to the recipient. However advice giving differs from 
other directives in that the advice giver intends their opinion or counsel to benefit the advice seeker, and thus Haverdake (1994) defines advice as a non-impositive directive. As with any speech act, contextual factors (e.g., issues of hierarchy, power and expertise) play a significant role in explaining why people express speech acts the way they do (Vine, 2009).

Advice offers are culture specific, in terms of both their level of directness and their structure. Levels of directness have been studied in a variety of speech acts and explained in relation to politeness considerations. Brown and Levinson's model (1978) predicts a strong correlation between politeness and indirectness based on a hierarchical model of politeness strategies. Similarly, Leech (1983: 108) argued that, given the same propositional content, speakers can "increase the degree of politeness by using a more and more indirect kind of illocution". According to Leech, "indirect illocutions tend to be more polite (a) because they increase the degree of optionality, and (b) because the more indirect an illocution is, the more diminished and tentative its force tends to be”. This assumed one-to-one correlation between indirectness and politeness has been called into question by researchers who noted that indirection does not always produce the most polite expressions (Escandell Vidal, 1995). The most obvious example is that of allusions, one of the off-record strategies identified by Brown and Levinson (1978), which, while being indirect, in many cases can be interpreted as expressing criticism of the hearer and thus threatening their image. It can be argued that, at least in informal situations, direct utterances softened with mitigating devices can produce more polite effects.

Cross-linguistic perspectives have challenged the correlation between indirectness and politeness. Blum-Kulka (1987), for instance, has questioned whether categorisations in terms of directness carry cross-culturally equivalent social meanings. She found that some direct patterns can be considered polite in a given situation in one culture and impolite in the same situation in another. Similarly, Wierzbicka (1991: 1991: 76f), notes great cross-linguistic variation in terms of directness, and argues that in many languages (e.g., Russian and Polish) the bare imperative is preferred and indirect speech acts are mostly avoided, while in other languages (e.g., English) directives tend to take an interrogative form or semi-interrogative form, and direct forms tend to be avoided, which she attributes to cross-cultural differences in the expression of politeness.

A further issue that has barely been raised so far pertains to the medium of communication. Most studies of speech acts have focused on oral interactions. However, the computerisation of culture has resulted in increasingly frequent exchanges in cyberspace, a medium that researchers believe is developing its own norms of communication (Domínguez Figaredo and Alonso Díaz, 2005; Herring, 2008; Thorne and Black, 2007). Language used in emails, chats and forums, although written, resembles what people do in conversations more than written discourse. Sentences, or rather, phrases, tend to be short, spontaneous, full of colloquialisms and emotion indicators (through the use of emoticons, diachronic symbols, flaunting of orthographic conventions), and generally constitute good illustrations of what Chomsky (1965: 3) characterised as 'performance', affected "by such grammatically irrelevant conditions as memory limitations, distractions, shifts of attention and interest, and errors". Given also the immediacy of on-line communication, it is at least 
possible that what is considered (im)polite in face-to-face interaction is interpreted differently in cyberspace interactions.

In the following sections, I discuss advice giving as presented in Spanish language textbooks before turning to advice on-line in Spanish.

\section{Advice giving in Spanish textbooks}

This section overviews the presentation of advice giving in 12 intermediate level Spanish language textbooks published in the US. Although the call to introduce pragmatic competence applies at all levels, intermediate level learners have been introduced to most linguistic structures, and thus instructors can presumably devote more time to pragmatic issues; hence the focus on this level of instruction. As mentioned in section §2, textbooks provide the primary, sometimes the only, source of linguistic input (in particular in the context of foreign language teaching), and are frequently used as the basis of the syllabus and curriculum. As such, they assume a crucial role in foreign language pedagogy.

Most of the books surveyed for this study (see list in Appendix 1) either claim to follow a communicative approach to language teaching, or mention the development of communicative competence among the aims of instruction. Familiarising students with Hispanic culture or, as put in Al Corriente, to offer students "fascinating insights into the people, cultures and societies" (p. xi) is also listed as a goal of most textbooks. There is also explicit recognition in some of the texts that, due to the growing interest in cultural competence, "instructional materials need to be not merely contextualized but also content-rich” (Pasaje: Lengua, p. xiii), and that learners require "extensive exposure to diverse forms of authentic language" to progress into advanced levels (Siempre Adelante, p. ix). These aims and considerations are important as stepping-stones to pragmatic competence, and therefore it is of great interest to see how the above-mentioned goals are translated into textbook materials and activities.

The first noticeable characteristic was that none of the texts lists 'advice' in the index or in the list of contents, which indicates that, if presented in the book, 'advice giving' would be subsumed under another category. This category turned out to be either a syntactic structure (typically the subjunctive mood, more rarely the imperative) or a function (e.g., how to express opinions or how to influence others). Consequently, the syntactic structures usually associated with advice were identified and the textbooks were analysed page-by-page to investigate the nature and extent of pragmatic information included. Because the distinction between advice and commands is not always clear-cut, and some of the textbooks do not separate these speech acts categorically, 'commands' were included in the survey. Interestingly, commands are the one single speech act listed in all textbooks' indexes.

Another common feature of the textbooks surveyed relates to the presentation of materials. Functions are mostly introduced through constructed dialogues devised to illustrate the structures to be taught, or through authentic readings. The purpose of the dialogues is to introduce new grammatical structures and not to provide a source for realistic conversational input. Readings, on the other hand, are usually excerpts from literary sources, and as such cannot be taken as reflections of language use in oral 
interaction. Following the dialogues or texts, the language structure under focus is discussed and illustrated by a few examples unaccompanied by contextual or situational information. Explanations are followed by the verbal paradigms and by exercises that require students to match together half-sentences, to complete sentences, to fill the gap by providing the correct conjugation of the verb given in brackets in infinitive form, or to orally drill the structure by asking and answering questions with a classmate. Despite claims to the contrary, then, all the textbooks surveyed continue to focus on the development of linguistic competence and exclude other aspects of language use.

Since context plays a crucial role in determining which formulas are used to realise particular speech acts, it would be expected that a variety of formulas be presented in Spanish language textbooks to suit diverse situations. Typically, however, advice giving in the textbooks surveyed is restricted to a few grammatical structures, some of which are given more space than warranted by their use in actual interaction (as, for instance, impersonal expressions as seen in Table 1, or performative verbs such as aconsejar 'advice' and recommender 'recommend'). This is problematic. As Vellenga (2004) noted in her study of speech act presentation in textbooks, "if students are provided with a one-to-one correspondence between language forms and functions, they are not able to develop a pragmatic toolbox with which to make choices about language and convey intentional illocutionary force”. Or, in Thomas's (1983) words, they are unable to flaunt conventional practices, if they chose to do so.

Another common practice in the textbooks examined is to illustrate the speech act with single sentences. Research has shown that this is an uncommon situation, given that usually speech acts are enacted in a number of turns (Daly, Holmes, Newton and Stubbe, 2004; Escandell Vidal, 1995; Holmes, 1998), each of which has a specific function in the text.

Table 1 provides a visual summary of advice giving as found in the textbooks surveyed. The first four columns list the syntactic structures used most frequently in the text to introduce advice giving in Spanish, and codes whether advice verbs are mentioned (m) among other verbs of will or influence, or explained as examples of a particular speech act (e), illustrated with sentence length examples (i) rather than with lists of representative verbs, and practiced (p). The remainder of the table summarises contextual and cultural information relevant to advice giving. Given the goals of instruction listed by the textbooks authors, we may expect at least some discussion on context of interaction and participants' roles. 
Table 1: Advice giving in intermediate level textbooks

\begin{tabular}{|c|c|c|c|c|c|c|c|c|c|c|c|c|c|c|c|c|c|c|}
\hline \multirow[b]{3}{*}{ Text } & \multicolumn{16}{|c|}{ Syntactic structure } & \multicolumn{2}{|c|}{ Pragmatic information } \\
\hline & \multicolumn{4}{|c|}{ Subjunctive } & \multicolumn{4}{|c|}{ Imperative } & \multicolumn{4}{|c|}{ Conditional } & \multicolumn{4}{|c|}{ Impersonal } & \multirow{2}{*}{$\begin{array}{l}\text { Contextual } \\
\text { information }\end{array}$} & \multirow{2}{*}{$\begin{array}{l}\text { Cultural } \\
\text { information }\end{array}$} \\
\hline & $\mathrm{m}$ & $\mathrm{e}$ & $\mathrm{i}$ & $\mathrm{p}$ & $\mathrm{m}$ & e & $\mathrm{i}$ & $\mathrm{p}$ & $\mathrm{m}$ & e & $\mathrm{i}$ & $\mathrm{p}$ & $\mathrm{m}$ & $\mathrm{e}$ & $\mathrm{i}$ & $\mathrm{p}$ & & \\
\hline Al corriente ( $3^{\text {rd }}$ ed. $)$ & $\Delta$ & & & $\Delta$ & & & & & $\Delta$ & & & & $\Delta$ & & $\Delta$ & $\Delta$ & no & yes \\
\hline Charlemos un poco ( $3^{\text {rd }}$ ed.) & $\Delta$ & & & & & & & & $\Delta$ & & & & $\Delta$ & & $\Delta$ & $\Delta$ & no & yes \\
\hline De paseo & $\Delta$ & & $\mathbf{\Delta}$ & $\mathbf{\Delta}$ & $\Delta$ & & $\boldsymbol{\Delta}$ & $\Delta$ & $\Delta$ & & & & $\Delta$ & & $\Delta$ & $\Delta$ & no & yes \\
\hline De perlas & $\Delta$ & & & & $\Delta$ & & $\Delta$ & $\Delta$ & $\Delta$ & & & & $\Delta$ & & & $\Delta$ & no & yes \\
\hline $\begin{array}{l}\text { Horizontes: Gramática y } \\
\text { conversación ( } 2^{\text {nd }} \text { ed.) }\end{array}$ & $\Delta$ & & & $\mathbf{\Delta}$ & & & & & & & & $\Delta$ & $\mathbf{\Delta}$ & & & $\mathbf{\Delta}$ & no & yes \\
\hline Interacciones & $\Delta$ & & $\Delta$ & $\Delta$ & & & & $\Delta$ & $\Delta$ & & $\Delta$ & $\boldsymbol{\Delta}$ & $\Delta$ & & $\Delta$ & $\Delta$ & no & yes \\
\hline Pasajes: Lengua (4 ${ }^{\text {th }}$ ed.) & & & & & $\Delta$ & & $\boldsymbol{\Delta}$ & $\mathbf{\Delta}$ & & & & & $\Delta$ & & $\Delta$ & $\Delta$ & no & yes \\
\hline $\begin{array}{l}\text { Puentes: Spanish for } \\
\text { intensive and high-beginner } \\
\text { courses }\end{array}$ & & $\Delta$ & $\Delta$ & $\Delta$ & & & & & $\Delta$ & & & & & & & & no & yes \\
\hline ¿Qué te parece? & & & & & & & & & & & & & $\Delta$ & & & $\Delta$ & no & yes \\
\hline Rumbos & $\Delta$ & & $\Delta$ & $\Delta$ & $\Delta$ & & $\Delta$ & $\Delta$ & & & & & $\Delta$ & & & & no & yes \\
\hline Siempre adelante & & $\boldsymbol{\Delta}$ & $\Delta$ & $\mathbf{\Delta}$ & & & & & $\Delta$ & & $\Delta$ & $\mathbf{\Delta}$ & $\Delta$ & & & $\Delta$ & some & yes \\
\hline Sigamos: Lengua y cultura & $\Delta$ & & $\Delta$ & $\Delta$ & $\Delta$ & & & $\Delta$ & & & & $\Delta$ & $\Delta$ & & & $\Delta$ & no & yes \\
\hline
\end{tabular}


As this table reveals, only three of the ten textbooks surveyed discuss advice as a speech act in its own right, and even these three discussions are very succinct. Siempre adelante, for instance, introduces advice through a constructed conversation followed by a table summarising the structure of advice and suggestions. Puentes provided a box illustrating three structures used to give advice (deberías 'you should' + infinitive, te aconsejo que 'I advise you' + subjunctive, ¿Por qué no...? 'why don't you' + present tense). This is followed by further instruction on the syntactic structure of the three patterns. Not only are the patterns presented in these texts insufficient to capture the variety of linguistic realisations speakers can use to offer advice, but also sociopragmatic information needed to explain appropriate use is absent from the discussion. The rest of the textbooks either mention advice as one of the many functions of the subjunctive mood - e.g., "in cause-and-effect relationships following verbs in the main clause which involve wanting, ordering, advising, prohibiting, allowing, or the negative of any of these" (De paseo, p. 135), "when the subject of the main clause attempts to influence someone else's behaviour” (De perlas, p. 200) - or do not mention advice at all.

Given that, as mentioned above, advice and commands are frequently collapsed in the textbooks examined, the second structure investigated was the imperative mood. Although imperatives are strongly associated with commands in all the textbooks surveyed, linguists have recognised that a variety of illocutionary acts are performed by this mood. Imperatives are used to give advice, admonish, threaten or command, to give permission and to make requests, among other functions (Durst-Andersen, 1995). However, only four of the ten textbooks mentioned advice among the functions of the imperative. Since the level of formality determines the choice of formal versus informal imperatives, contextual information plays a crucial role. Yet, the only factor mentioned with regard to context relates to familiarity and/or age of the conversation participants. Other contextual variables (e.g., status, gender, time, place) are ignored. On using the imperative, some of the texts warn students that imperatives are strong commands, and recommend adding the expression por favour 'please' whenever possible (De perlas, p. 161, De paseo, p. 96) to mitigate the strength of the utterance.

The use of the conditional is similarly explained in terms of politeness, as a softening strategy that contrasts with the imperative. There is no discussion, however, of the contexts or situations in which speakers may choose to soften their speech, assuming that learners are able to transfer this information from their native language and that this information from their native language is appropriate for transfer into Spanish. De paseo, for instance, reminds students that in real life, advice "can be direct or softened with por favour", but unhelpfully concludes, "Let the situation determine which form you use” (p. 97), which ignores the speaker's role - and thus their pragmatic requirement for cultural knowledge - in interpreting the situation. Furthermore, there is no mention of other mitigation devices that native speakers use. As shown below in the discussion of on-line data, commands can serve to establish solidarity, and encourage or show empathy with the advice seeker among other functions, and can be mitigated by other means such as using humour, nicknames, tags, and other such strategies. The textbooks thus favour 'respect', which in many cases can produce or reinforce distance between speakers, over other interpersonal relations, such as solidarity, which may actually draw the learner closer to speakers of the target language, thus increasing the learner's exposure to quantity and quality of input. 
Finally, impersonal expressions, called 'value judgement expressions' in some textbooks, are listed in most textbooks but treated only summarily, without explicit discussion of the wide range of functions these expressions serve. Furthermore, none of the textbooks examined reflects on the appropriateness of using these expressions vis-à-vis expressions in which the subject can be clearly identified.

Cultural information can be found in all the surveyed textbooks, mostly via readings. The focus of the cultural component is on Spanish literature or on aspects of life in Spanish speaking countries, with no discussion of the mutual interaction between culture and language. This is exacerbated by the heavy focus on linguistic competence and neglect of other aspects of communication. Pragmatic information could narrow this divide, but the textbooks fail to provide sufficient contextual information that learners need to develop sociolinguistic competence. This shortcoming leaves learners potentially able to use the syntactically correct structures but with insufficient pragmalinguistic control over whether, when and why to use these structures to convey the intended meanings (Bardovi-Harlig, Hartford, Mahan-Taylor, Morgan and Reynolds, 1991; Cohen, 2005).

To summarise the discussion so far, the survey shows the shortcomings of Spanish language textbooks on the task of giving advice. The textbooks' explanations fall short of accurately describing how and why speech acts are realised, and do not discuss the social strategies that underlie speakers' choices. These shortcomings leave learners without the pragmatic linguistic knowledge they need to express themselves as they intend and, to some extent, to develop interpersonal relations that maximise their exposure to quantity and quality of input. We now turn to the second data set, on-line advice.

\section{Advice giving on-line}

\subsection{The data}

The corpus of advice giving analysed in this paper was collated from responses to 17 questions posted by males and females in 2008-2009 on eight websites (Appendix 2 lists forum titles). The questions ask for advice on how to break up with a boyfriend/girlfriend without hurting their feelings. A total of 232 posts were obtained from 185 contributors. One hundred and seventy of the posts indicated the gender of their contributor - 96 from males and 74 from females - while for the remaining 62 posts the contributor's gender was unspecified.

The vast bulk of posts (203) were treated as advice, on the basic criteria that they used 1) overt recommendations (yo te aconsejo que hables con ella sobre su relacion y lo que no esta funcionando 'I advise you to talk to her about your relationship and what is not working'); 2) imperatives or subjunctives following negation (Dale tiempo 'Give her time'; No te engañes más Brad Pitt 'Do not deceive yourself any longer, Brad Pitt'); 3) modal verbs of obligation (Tenes que estar seguro de eso 'You have to be sure of that'); or 4) value judgement or impersonal expressions (Es mas facil dejar una relacion en menor tiempo posible 'It is easier to leave a relationship as soon as possible'); or that the response consisted of a personal experience that offered an implicit but unambiguous suggestion. 
These criteria ruled out responses that were limited to sharing an experience and did not propose a solution, or where the focus was on criticising - or even abusing - the advice seeker. As the list of sites in Appendix 2 reveals, all except for Yahoo Mexico and Vogue España were from Argentina. However, due to the global accessibility afforded by the Internet, the background of the respondents was more varied, as evident in the use of regionalisms that are not used in Argentinian Spanish, and that could not be identified in many instances. For this reason, respondents' backgrounds, which could have yielded cross-dialectal differences, were ignored in this study.

Another problematic area was respondents' gender, which cannot be established with absolute certainty given the nature of internet posting. Since the main aim of this paper is to analyse features of on-line advice discourse and not to identify discourse to socialise learners into gender roles, this aspect of the study was not explored further.

\subsection{Analysis}

The data collected were read and coded. The first step in the analysis was to identify the varied discursive moves found in each response. The simpler response type, bald advice, can be seen in (1).

$$
\begin{aligned}
& \text { Dicelo tibiamente }{ }^{1} \text { [advine] } \\
& \text { say:to him:it gently } \\
& \text { 'Tell him gently.' }
\end{aligned}
$$

In line with the literature on advice discourse (e.g. DeCapua and Findlay Dunham, 2007; Locher, 2006), and unlike the single-sentence presentation noted in textbooks, advice was generally embedded within other discursive moves. These moves typically function as means to frame the advice in such a way that makes it acceptable to the advice seeker. The moves found most frequently in the data were assessments and elaborations. Following Locher (2006), I take 'assessment' to be "a passage in which the advice seeker's particular situation is mentioned and evaluated" (2006: 63), while 'elaboration' is taken to be an explanation of a point just made. In (2) and (3) below, advice, assessments and elaborations are indicated in square brackets following the relevant move.

(2) Y mira, es jodido. Vos seguramente no queres lastimarlo, and look, it is screwed. You surely not want to:hurt:him, pero por hacer eso, te estas lastimando vos [assessment]. Tenes but because to:do that, you are hurting you. (you) have que pensar un poco mas en vos y cortar por lo sano. [advice] to think a bit more in you and to:break for the sane.

'Well, look, it is hard. You most probably don't want to hurt him, but by doing that you are hurting yourself. You have to think a bit more about yourself and make a clean break'.

(3) Deberías dejar esa relación hasta ahí!! [advice] Le haces (you) should leave that relationship up:to there!! him hurt:you

\footnotetext{
${ }^{1}$ Data are presented as written by the contributors, without editing the syntax or orthography. The only change is the Italianisation of the Spanish examples. Case was kept as in the original text.
} 
mucho más daño estando con él, sin sentir nada, solo

much more damage being with him, without to:feel nothing, only

una amistad! [elaboration]

a friendship

'You should leave that relationship up there! You do him much more damage by being with him without feeling anything, just friendship!'

Other frequent moves found in the data include mentioning shared experiences (4) as a means to establish solidarity or showing empathy with the advice seeker, or discussing one's own experiences (5) as a way to establish the respondent's suitability to offer advice. The positive outcome mentioned in (5) also serves as a means of encouragement.

FLACO [nickname] A MI ME PASA EXACTAMENTE LO MISMO QUE VOS

... [shared experience]

skinny, to me it happens exactly the same as you

'Dude, exactly the same is happening to me.'

(5) ami tambien me pasaba exactamente igual [shared experience], la intentaba dejar i se ponia a llorar i me acia sentir mal siempre como si io fuera el malo, al final le pude poner valor i hace unos cuantos meses que acabo lo nuestro, dejarla es lo mejor que echo, [own experience] al principio te sentiras mal pero despues lo agradeceras y tus amigos tambien

'Exactly the same used to happen to me. I tried to leave her and she would start crying and always made me feel bad as if I were the bad guy, finally I muster some courage and a few months ago our relationship ended, leaving her is the best thing I've done, initially you'll feel bad but later you'll be thankful and your friends will too'.

A number of moves can be classed under the category 'expressing empathy'. These include using nicknames (see 4 above), greetings and farewells, encouraging expressions, offers of additional help, use of tag questions, use of second person plural pronouns, and use of emoticons (as in (5)). Some of these features are illustrated in (6)

(6) como le fue compadrito [nickname]

arreglo su problema yo aun estoy igual que tu

no logro hacer nada para que ella cambie [shared experience]

te dejo mi correo para que podamos hablar [offer of additional help]

si alguien mas quiere agregarme seria genial

esto lo debemos arreglar [encouragement]

saludos cordiales. [farewell]

'How did it go, hoodlum?

Did you solve your problem the same as is happening to me

I don't manage to do anything for her to change

I'm leaving you my email so that we can talk

If someone else wants to add me it would be great

We can solve this

Warm regards. 
Disclaimers, that is, admissions that the respondent is not able or qualified to offer advice since he or she is in the same situation, sometimes follow mentions of shared experience, but this move was infrequent in the data $(n=3)$, as were referrals to professional help $(n=1)$, common in on-line medical advice (Locher, 2006).

The next step in the analysis involved separating the specific units of advice from other moves of advice discourse illustrated above. Responses contained one to seven units of advice, and thus the 203 responses classed as advice yielded a total of 639 advice units (means $=3.1$ per response). These units were further coded according to their syntactic structure into declarative, imperative and interrogative phrases. After examining the data, a fourth category was added, consisting of non-verbal or nonfinite constructions.

\subsection{Results}

Table 2 displays the results for syntactic formula in on-line data. The table indicates that there were striking differences between these data and the textbook formulas. The most obvious difference is the online low frequency use of declarative sentences (one subtype of which would be sentences containing a subjunctive clause following advice verbs) and high frequency use of the imperative mood, which textbooks typically associated with commands. Because interrogative sentences, non-verbal and non-finite constructions were used very infrequently, they are not discussed here.

Table 2: Distribution of syntactic formula in on-line data $(n=639)$

\begin{tabular}{llll}
\hline Imperatives & Declaratives & Non-verbal/non-finite & Interrogatives \\
\hline $453(71 \%)$ & $159(24 \%)$ & $23(4 \%)$ & $4(1 \%)$ \\
\hline
\end{tabular}

Further examination of the data reveals that a much wider range of formulas has been used in the online advice than what is presented in textbooks. Table 3 presents a summary of advice patterns found in the data. The response type is given in the left column, followed by an example in the right column.

Table 3: Advice offers in on-line data

\begin{tabular}{ll}
\hline Type & Example \\
amperatives & $\begin{array}{l}\text { Dale tiempo } \\
\text { Give him time } \\
\text { b. Subjunctives following negation }\end{array}$ \\
& $\begin{array}{l}\text { No te engañes más Brad Pitt } \\
\text { Don't fool yourself any longer Brad } \\
\text { Pitt } \\
\text { debes de esperarte } \\
\text { you have to wait }\end{array}$ \\
Declaratives & $\begin{array}{l}\text { Mi consejo es que hables con la } \\
\text { a. Present tense }\end{array}$ \\
& $\begin{array}{l}\text { My advice is that you talk to the } \\
\text { person who treats her } \\
\text { yo te digo q tenes } q \text { no hablarle } \\
\text { I'm telling you that you need to not } \\
\text { talk to her }\end{array}$ \\
&
\end{tabular}


c. Present tense with imperative force (presente de mandato)

d. Future tense with imperative force

\section{e. Conditional}

f. Value judgement and impersonal expressions

g. Subjunctive in independent clauses

\section{Interrogatives}

Non-verbal/non-finite constructions le dices que ya no quieres seguir con

ella

you tell her that you don't want to continue with her any longer podrás intentar atenuar ese dolor, si al dejarla le explicas tus motives You will try to alleviate that pain if, when you leave her, you explain your reasons tendrías que respetarte a ti mismo You would have to respect yourself es mas facil dejar una relacion en menor tiempo possible it's easier to leave a relationship in the shortest time possible

hay que actuar con un poco de

frialdad

one must act a bit cool

que no te descubran

that they don't discover you

Por q no hablas con la familia y listo

Why don't you talk to the family and

that's it

basta de dar vueltas!

Enough of spinning around!

\subsubsection{On-line imperatives}

As can be seen in Table 2, imperatives were the most frequently used mood on-line. The majority of expressions are of a kind that the textbook calls 'positive commands', maybe reflecting a tendency by respondents to tell advice seekers positive measures to take rather than what to avoid. The second most frequent strategy is represented by the so-called 'negative command'. Since negation is incompatible with second person imperatives, the subjunctive is used in this case. Interestingly, few textbooks mention that the 'negative commands' are in fact subjunctives, leaving students with the impression that they need to master two verbal paradigms. Modal verbs of obligation were not frequent in the data, and included mostly positive commands. Also infrequent were subjunctives in independent clauses. The distribution of imperatives is given in Table 4.

Table 4: Distribution of imperatives in on-line data $(\mathrm{n}=453)$

\begin{tabular}{lll}
\hline Positive & Negative & Modal verbs \\
\hline $348(54 \%)^{2}$ & $75(12 \%)$ & $30(5 \%)$ \\
\hline
\end{tabular}

\footnotetext{
${ }^{2}$ Percentages were obtained by dividing the number of tokens of particular structures by the number of advice units (i.e. $n=639$ )
} 


\subsubsection{On-line declaratives}

As Table 5 reveals, declarative sentences showed a wide range of patterns. However, the distribution of these advice patterns, with the exception of impersonal and value judgement expressions, was extremely low.

Table 5: Distribution of declaratives in on-line data $(\mathrm{n}=159)$

\begin{tabular}{|l|l|l|l|l|l|l|}
\hline Impersonal & $\begin{array}{l}\text { Present }+ \\
\text { Subordinated } \\
\text { clause }\end{array}$ & Conditional & $\begin{array}{l}\text { Present } \\
\text { w/imper. } \\
\text { force }\end{array}$ & $\begin{array}{l}\text { Present } \\
+ \text { modal } \\
\text { verb }\end{array}$ & $\begin{array}{l}\text { Subjunctives } \\
\text { in } \\
\text { independent } \\
\text { clauses }\end{array}$ & Future \\
\hline $61(10 \%)$ & $32(5 \%)$ & $22(3 \%)$ & $19(3 \%)$ & $12(2 \%)$ & $9(1 \%)$ & $4(0.5 \%)$ \\
\hline
\end{tabular}

The most frequently used structures are impersonal and value judgement expressions, to which most language textbooks devote about half a page. Interestingly, performative verbs of advice followed by subjunctives, the pattern presented as the canonical advice structure and to which all textbooks devote considerable space, accounts for only 5 per cent of the total units of on-line advice, closely followed by the conditional and modal verbs, which most books mention summarily. Finally, present and future verbs with imperative force are absent from textbook discussions of advice giving, even though these are valid options as the on-line data attest.

\section{Discussion and conclusion}

This study has explored how one particular speech act, advice giving, is presented in intermediate Spanish language textbooks, and how this presentation compares with naturally occurring on-line data. The comparison between the two datasets reveals striking differences. With regard to pragmalinguistics, textbooks seem to adhere to a one-to-one correlation between form and function, and thus introduce a limited range of structures: declarative sentences consisting of performative advice verbs followed by subordinated subjunctive clauses to offer advice; imperative clauses to issue commands. As section $\$ 5.3$ indicates, however, advice can be given in different forms, including imperatives and interrogatives, in addition to declaratives. Thus, not only do the textbook formulas underrepresent the range of linguistic resources available in Spanish, they also misrepresent the distribution of formulas in naturally occurring data, ignoring frequently used structures and devoting too much attention to structures used infrequently. It could be argued that regardless of frequency of their use, learners need to acquire certain structures - such as the subjunctive - in order to develop accuracy, so that considerable class time needs to be devoted to teaching and testing them. This may be the case, but note that underlying this argument is the assumption that linguistic competence is still the primary aim of instruction, taking precedence over other aspects of communication. 
A second issue discussed in this paper relates to sociopragmatic information presented in textbooks. As shown in $\S 4$, no discussion in any of the textbooks surveyed gives learners an indication of pragmatic norms operating in the target culture. The cultural information that the textbooks introduce, although interesting, is irrelevant for communication purposes. Only one interpersonal relationship is mentioned in some books to help learners select between formulas, and this is to show respect. While this is undoubtedly important, learners are thus socialised to be "'hypercorrect', both grammatically and pragmatically” (Thomas, 1983: 96). The textbooks also ignore ways of establishing solidarity, amply exemplified in the naturally collected data, even though these could be the tools to facilitate and enhance learners' interactions with target language speakers, thus increasing availability of input to them.

While it is true that subjunctives are usually used in expressions of pragmatic courtesy, the on-line data showed a marked preference for imperatives. The questions can be asked, then: Are Spanish advice givers impolite? And does the nature of online communication invite a less formal mode of communication? We cannot determine the respondents' intentions. Also, since there is no response to the advice given, we cannot ascertain how advice seekers respond to bald directives, and therefore we can only speculate. What is remarkable in the data is the range of mitigating devices that advice givers use, frequently softening imperatives by attenuating elements such as modalisers, expressions of empathy, use of nicknames, adulation, expressions of affection and encouragement, and even use of emoticons. Elaborating or giving reasons for the advice also act as mitigating procedures. Briz (2002) suggests that in Spanish conversations, mitigation is used as a strategic resource to seek the acceptance of the listener, either through the message or the speaker him/herself, and thus relates to face establishment. Politeness is therefore not an end in itself but a means to an end. In the case of advice, this end is to mitigate the potential threat of the advice offered and to make it more acceptable to the receiver.

Yet in on-line advice, the use of imperatives has another interpretation, which relates to contextual variables. Vine (2009), for instance, in her study of directives in the workplace, has shown that the use the use of the imperatives is frequent when a directive is directly elicited, such as in problem-solving interaction. A second contextual aspect relates to the features of the internet as the medium of communication. Some have observed that language used on the internet tends towards short, concise, syntactically simple and direct messages. It may well be that in advice situations, where the advice seeker and giver do not know each other, hierarchy considerations are less relevant to both parties. Someone requesting advice may appear to be placing the advice giver in the 'expert role', but the anonymity of all participants and the lack of follow-up in the interaction means that the advice seeker is not compelled to accept the advice offered nor to have any relationship whatsoever with the advice giver, and therefore issues of face play a smaller role and for some participants perhaps none at all. It may well be that the elicited nature of the advice, the lack of continuity in the interaction and the impossibility of the advice recipient to ask for clarification bring other pragmatic principles to play, related to the relevance, clarity and economy of the message (cf. Blum-Kulka, 1987).

A final point relates to the suitability of these data in the foreign language classroom. The on-line data discussed here clearly do not depict naturally occurring advice in Spanish; they represent one particular context of interaction and thus the results 
should be treated with caution. This context, however, is one to which learners are naturally attracted, as evidenced by the sheer expansion in the number of on-line users, and thus it has great potential for language teaching and learning, particularly through increasing learners' exposure to authentic materials and providing examples of pragmatic interactions and insights into cultural mores from which learners have much to benefit. Note that the focus is on exposure to, not imitation of, native speakers. Raising learners' awareness of the pragmatic conventions of the target culture is a crucial first step for acquiring pragmatic competence (Cenoz, 2007; Cohen, 2005), but learners may not need or want to go further in the acquisition path. Awareness raising may be enough to help the learner develop sensitivity towards pragmatic behaviour in the target culture (Cohen, 2005), to prevent misattribution or faulty assessment of other participants' intentions, and to equip learners to express themselves the way they choose to do so "- rudely, tactfully, or in an elaborately polite manner” (Thomas, 1983: 96). These goals can be achieved only through data collected directly from speakers/writers of the target language in authentic contexts. This kind of data may not be able to substitute for foreign language textbooks, but should surely be used to supplement them.

\section{References}

Bachman, Lyle F. 1990. Fundamental Considerations in Language Testing. Oxford University Press, Oxford

Bardovi-Harlig, Kathleen, Dörnyei, Zoltán. 1998. Do language learners recognize pragmatic violations? Pragmatic versus grammatical awareness in instructed L2 learning. Tesol Quarterly, 32(2), 233-262.

Bardovi-Harlig, Kathleen, Hartford, Beverly A. S. , Mahan-Taylor, Rebecca, Morgan, M. J. , Reynolds, D. W., 1991. Developing pragmatic awareness: Closing the conversation. ELT Journal Volume, 45(1), 4-15.

Blum-Kulka, Shoshana. 1987. Indirectness and politeness in requests: Same or different? Journal of Pragmatics, 11, 131-146.

Boxer, Diana, Pickering, Lucy. 1995. Problems in the presentation of speech acts in ELT materials: The case of complaints. ELT Journal, 49(1), 44-58.

Briz, Antonio. (2002). La estrategia atenuadora en la conversación cotidiana española. Paper presented at the Primer coloquio del programa EDICE, Stockholm.

Brown, Penelope, Levinson, Stephen. 1978. Universals of language usage: Politeness phenomena. In E. Goody (Ed.), Questions and Politeness (pp. 56-324). Cambridge University Press, Cambridge

Canale, M., 1983. From communicative competence to communicative language pedagogy. In C. J. Richards \& R. Schmidt (Eds.), Language and Communication (pp. 2-27). Longman, London

Canale, Merrill, Swain, Michael. 1980. Theoretical bases of communicative approaches to second language teaching and testing. Applied Linguistics, 1, 147.

Cenoz, Jasone. 2007. The acquisition of pragmatic competence and multilingualism in foreign language contexts. In E. Alcon Soler \& M. P. Safont Jordà (Eds.), Intercultural Language Use and Language Learning (pp. 123-140). Springer Netherlands, Dordrecht

Chomsky, N. 1965. Aspect of the Theory of Syntax. MIT Press, Cambridge, Mass. 
Cohen, A. D., 2005. Strategies for learning and performing L2 speech acts. Intercultural Pragmatics, 2(3), 275-301.

Daly, Nicola, Holmes, Janet, Newton, Jonathan, Stubbe, Maria. 2004. Expletives as solidarity signals in FTAs on the factory floor. Journal of Pragmatics, 36(5), 945-964.

DeCapua, Andrea, Findlay Dunham, Joan. 2007. The pragmatics of advice giving: Cross-cultural perspectives. Intercultural Pragmatics, 4(3), 319-342.

Dlaska, Andrea. 2000. Integrating culture and language learning in institution-wide language programmes'. Language, Culture and Curriculum, 13(3), 247-263.

Domínguez Figaredo, Daniel, Alonso Díaz, Laura. 2005). Evaluación mixta de comunidades de aprendizaje en línea. http://www.cibersociedad.net/archivo/articulo.php?art=205. Retrieved February 4, 2010

Durst-Andersen, Per. 1995. Imperative frames and modality: Direct vs. indirect speech acts in Russian, Danish, and English. Linguistics and Philosophy, 18(6), 611-653.

Escandell Vidal, M. V., 1995. Cortesía, fórmulas convencionales y estrategias indirectas. Revista española de lingüística, 25(1), 31-66.

Firth, Alan, Wagner, Johannes. 1997. On discourse, communication, and (some) fundamental concepts in SLA research. The Modern Language Journal, 81(3), 285-300.

Haverkate, Henk. 1994. La cortesía verbal: estudio pragmalingüístico. Gredos, Madrid

Herring, Susan. C., 2008. Language and the Internet. In W. Donsbach (Ed.), International Encyclopedia of Communication (pp. 2640-2645). Blackwell Publishers, Malden, MA; Oxford

Holmes, Janet. 1998. Complimenting - A positive politeness strategy. In J. Holmes (Ed.), Language and Gender: A Reader (pp. 100-120). Blackwell Publishers,

Hymes, Dell. 1971. Competence and performance in linguistic theory. In R. Huxley \& E. Ingram (Eds.), Language Acquisition: Models and Methods (pp. 3-28). Academic Press, London

Kasper, Gabriele. 1997). Can pragmatic competence be taught? (NetWork \#6) [HTML document]. Honolulu: University of Hawai'i, Second Language Teaching \& Curriculum Center. Retrieved 30/01/2010 from the World Wide Web: http://www.nflrc.hawaii.edu/NetWorks/NW06/

Kasper, Gabriele, Rose, Kenneth R. 2002. Pragmatic Development in a Second Language. Blackwell, Malden, Mass. ; Oxford

Kramsch, C., 1997. The privilege of the nonative speaker. PMLA, 112(3), 359-369.

Leech, G. 1983. Principles of pragmatics. Longman, London/New York

Liddicoat, Anthony J., 1997. Interaction, social structure, and second language use: A response to Firth and Wagner. The Modern Language Journal, 81(3), 313-317.

Locher, Miriam A. 2006. Advice Online: Advice-giving in an American Internet Health Column. John Benjamins, Amsterdam/Philadelphia

Martínez-Flor, Alicia, Alcón Soler, Eva. 2007. Developing pragmatic awareness of suggestions in the EFL classroom: A focus on instructional effects. Canadian Journal of Applied Linguistics / Revue canadienne de linguistique appliquee, 10(1), 47-76.

Matsumura, Shoichi. 2001. Learning the rules for offering advice: A quantitative approach to second language socialization. Language Learning, 51(4), 635679. 
Morrow, Phillip R., 2006. Telling about problems and giving advice in an Internet discussion forum: Some discourse features. Discourse Studies, 8(4), 531-548.

Searle, John. 1969. Speech Acts: An Essay in the Philosophy of Language. Cambridge University Press, Cambridge

Seedhouse, Paul. 1996. Classroom interaction: Possibilities and impossibilities. ELT Journal, 50(1), 16-24.

Thomas, Jenny. 1983. Cross-cultural pragmatic failure. Applied Linguistics, 4, 91112.

Thorne, Steven L. , Black, Rebecca W., 2007. Language and literacy development In computer-mediated contexts and communities. Annual Review of Applied Linguistics, 27, 133-160.

Vellenga, Heidi. 2004. Learning pragmatics from ESL \& EFL textbooks: How likely? TESL-Electronic Journal, 8(2), 1-18.

Vine, Bernadette. 2009. Directives at work: Exploring the contextual complexity of workplace directives. Journal of Pragmatics, 41(7), 1395-1405.

Wierzbicka, Anna. 1991. Cross-cultural Pragmatics: The Semantics of Human Interaction. Mouton de Gruyter, Berlin/New York

\section{Appendix 1: Textbooks surveyed}

Ascarrunz Gilman, G., N. Levy-Konesky \& K. Daggett. (2005) Horizontes:

Gramática y conversación, 4/e. Heinle \& Heinle

Blake, R. J., M. V. González Pagani, A. Ramos \& M. Alford Marks (1998) Al

corriente: Curso intermedio de español, 4/e. McGraw-Hill

Bretz, M. L., T. Dvorak, C. Kirschner \& R. Bransdorfer (2003) Pasajes: Lengua, 5/e. McGraw-Hill

Cubillos, J. H. (1996) Siempre Adelante: A Brief Course For Intermediate Spanish. Heinle \& Heinle

Jarest, R., J. Robinson \& M. Fernandez (1995) Charlemos un poco, 3/e. Heinle \& Heinle

Labarca, A., E. A. Rodríguez \& O. G. González (1997) De Perlas: Intermediate Spanish., John Wiley \& Sons

Lee, J. F., D. J. Young, D. F. Wolf, \& P. M. Chandler (1998) ¿Qué te parece? McGraw-Hill

Marinelli, P. J. \& L. Mujica Laughlin (1994) Puentes: Spanish for Intensive and High-beginner Courses, Heinle \& Heinle

Pellettieri, J., N. López-Burton, R. Hershberger, R. Gómez \& S. Navey-Davis (2008) Rumbos. Heinle \& Heinle

Reseigh Long, D. \& J. L. Macián (2005) De paseo: Curso intermedio de español, 3/e. Heinle \& Heinle 
Spinelli, E., García C. \& C. E. Galvin Flood (2009) Interacciones, 6/e. Heinle \& Heinle

Vélez Román, L. \& J. Córdova (1998) Sigamos: Lengua y cultura, McGraw-Hill

\section{Appendix 2: Websites consulted}

Acomplejados 1 www.acomplejados.com.ar/2008/12

Acomplejados 2 http://www.acomplejados.com.ar/2007/03/24/no-puedo-dejar-a-minovia/

Acomplejados 3 http://www.acomplejados.com.ar/2009/01/10/no-amo-a-mi-noviaquiero-dejarla/

EnFemenino http://foro.enfemenino.com/forum/f101/_f1498_f101-No-se-comodejar-a-mi-novia.html

EnFemenino 2 http://foro.enfemenino.com/forum/pareja1/_f102033_pareja1-Quieroterminar-con-mi-novia-sin-erirla.html

PSICOFXP http://www.psicofxp.com/forums/amor-y-pareja.178/941945-como-lodejo.html

PSICOFXP http://www.psicofxp.com/forums/amor-y-pareja.178/941945-como-lodejo.html

Yahoo Argentina

http://ar.answers.yahoo.com/question/index; ylt=Aj5k486rQC9T.rfMCVMGf5Wp9gt

$\therefore$ ylv=3?qid=20090713173418AAygB45

Yahoo Argentina 2

http://ar.answers.yahoo.com/question/index?qid=20061002171601AAG4W2p

Cualquiera http://www.foro-cualquiera.com/tus-problemas/66328-quiero-dejar-minovio-no-se-hacerlo.html

Tus preguntas http://tuspreguntas.misrespuestas.com/preg.php?idPregunta=10399

Yahoo Mexico

http://mx.answers.yahoo.com/question/index?qid=20060801121625AASypCT

Yahoo Mexico http://mx.answers.yahoo.com/question/index?qid

Vogue España http://foros.vogue.es/viewtopic.php?f=47\&t=152547 
